\title{
Adsorption of metal and metalloid ions onto nanoporous microparticles functionalized by atomic layer deposition
}

\section{Nanoporous microparticles for metal and metalloid ions adsorption}

Xiaofeng Wang ${ }^{a}$, Ariel R. Donovan ${ }^{\text {b,c }}$, Rajankumar L. Patel ${ }^{a}$, Honglan Shi ${ }^{\text {b,c }}$, and Xinhua Liang ${ }^{a, b, *}$

${ }^{a}$ Department of Chemical and Biochemical Engineering, Missouri University of Science and Technology, Rolla, MO 65409, United States

${ }^{\mathrm{b}}$ Center for Single Nanoparticle, Single Cell, and Single Molecule Monitoring $\left(\mathrm{CS}^{3} \mathrm{M}\right)$, Missouri University of Science and Technology, Rolla, MO 65409, United States

${ }^{\mathrm{c}}$ Department of Chemistry, Missouri University of Science and Technology, Rolla, MO 65409, United States

*Corresponding author, Email: liangxin@mst.edu

\begin{abstract}
A novel material was prepared by depositing ultrathin $\mathrm{TiO}_{2}$ films on nanoporous micron-sized silica gel particles by atomic layer deposition (ALD). Silica gel particles were coated with 20 and 40 cycles of $\mathrm{TiO}_{2}$ films by ALD. Half samples were heated at $500{ }^{\circ} \mathrm{C}$ to change the crystal structure of $\mathrm{TiO}_{2}$. Their adsorption ability for a mixture of 19 trace elements of heavy metals and other toxic elements, including $\mathrm{As}(\mathrm{V}), \mathrm{Se}(\mathrm{IV}), \mathrm{Be}(\mathrm{II}), \mathrm{Al}(\mathrm{III}), \mathrm{V}(\mathrm{V}), \mathrm{Cr}(\mathrm{III}), \mathrm{Mn}(\mathrm{II}), \mathrm{Co}(\mathrm{II})$, $\mathrm{Ni}(\mathrm{II}), \mathrm{Cu}(\mathrm{II}), \mathrm{Zn}(\mathrm{II}), \mathrm{Ba}(\mathrm{II}), \mathrm{Tl}(\mathrm{I}), \mathrm{Sb}(\mathrm{III}), \mathrm{Cd}(\mathrm{II}), \mathrm{Ag}(\mathrm{I}), \mathrm{Sr}(\mathrm{II}), \mathrm{Mo}(\mathrm{VI})$, and $\mathrm{Pb}(\mathrm{II})$, from aqueous solutions was investigated. The removal efficiencies of $\mathrm{As}(\mathrm{V}), \mathrm{Se}(\mathrm{IV}), \mathrm{V}(\mathrm{V}), \mathrm{Mo}(\mathrm{VI})$, and $\mathrm{Pb}$ (II) were higher than $75 \%$ simultaneously in the mixed solution at $\mathrm{pH} 3$ for 20 and 40
\end{abstract}


cycles of $\mathrm{TiO}_{2}$ coated silica gel particles without heat treatment. In contrast, the uncoated silica gel particles did not adsorb any ions under this $\mathrm{pH}$ condition. At $\mathrm{pH} 5$, the 20 cycles of $\mathrm{TiO}_{2}$ coated samples without heat treatment removed 95\% As(V), 95\% Se(IV), 86\% V(V), 94\% $\mathrm{Mo}(\mathrm{VI}), 69 \% \mathrm{~Pb}(\mathrm{II}), 40 \% \mathrm{Sb}(\mathrm{III}), 73 \% \mathrm{Ag}(\mathrm{I}), 72 \% \mathrm{Cu}(\mathrm{II})$, and $49 \% \mathrm{Ba}(\mathrm{II})$ simultaneously. Before heat treatment, the $\mathrm{TiO}_{2}$ coated samples showed better adsorption performance than the samples with heat treatment due to the fact that the $\mathrm{TiO}_{2}$ surface area decreased and thereby the amount of adsorption sites reduced after heat treatment. The micron-sized adsorbent particles were separated easily from water due to their large particle size, making it practically suitable for trace contaminant remediation in water.

Keywords: atomic layer deposition (ALD), water treatment, trace element, nanoporous silica particle, $\mathrm{TiO}_{2}$

\section{Introduction}

Heavy metal and metalloid pollution has become one of the most important environmental concerns. When present in water, toxic heavy metal and metalloid ions, such as lead $(\mathrm{Pb})$, manganese (Mn), chromium (Cr), and arsenic (As), can directly affect the environment and human health $[1,2]$. For example, $\mathrm{Cr}, \mathrm{Pb}$ and $\mathrm{Mn}$ can cause brain and bone damage, As can cause cancer, and $\mathrm{Cr}$ can cause liver and kidney damage [3]. Hence, it is important to remove these ions from contaminated waste water to an acceptable, non-toxic level before being discharged to receiving water or being consumed as drinking water. Toxic heavy metal ions and 
metalloids can be removed by many techniques, such as ion exchange [4], membrane filtration [5], reverse osmosis [6], chemical precipitation [7], evaporation [8], and sorption [2, 9-17]. Among these methods, adsorption is one of the most effective and economical methods for the removal of heavy metal and metalloid ions from contaminated water, especially at low concentrations due to its high efficiency, simple operation, and low cost $[2,18]$. Numerous studies focused on adsorbent preparation and adsorption process, such as using $\mathrm{TiO}_{2}$ and $\mathrm{Al}_{2} \mathrm{O}_{3}$ nanoparticles (NPs) as adsorbents $[2,9-15]$. $\mathrm{TiO}_{2}$ was proven to have a high removal capability because of its promising properties, such as biological and chemical inertness, high adsorption capacity, photoactivity, and environment-friendly [19-21].

$\mathrm{TiO}_{2}$ NPs have shown excellent adsorption ability for heavy metal and metalloid ions from aqueous solutions due to their high surface area. Li et al. [2] and Qian et al. [9] prepared $\mathrm{TiO}_{2}$-graphene oxide core-shell microspheres and $\mathrm{C} / \mathrm{TiO}_{2} \mathrm{NPs}$ with a maximum adsorption capacity for $\mathrm{Cr}(\mathrm{III})$ of 117.9 and $18.1 \mathrm{mg} / \mathrm{g}$, respectively. Wu et al. [10] synthesized a chitosan-xylan- $\mathrm{TiO}_{2}$ hybrid with highly porous structures with maximum adsorption capacities for $\mathrm{Cu}(\mathrm{II}), \mathrm{Ni}(\mathrm{II}), \mathrm{Cd}(\mathrm{II})$ and $\mathrm{Hg}(\mathrm{II})$ of $158.7,96.2,78.1$ and $76.3 \mathrm{mg} / \mathrm{g}$, respectively. Abbasizadeh et al. [14] reported the adsorption of $\mathrm{Cd}(\mathrm{II}), \mathrm{Ni}(\mathrm{II})$ and $\mathrm{U}(\mathrm{VI})$ separately by a cast polyvinyl alcohol/ $\mathrm{TiO}_{2} /$ APTES (aminopropyltriethoxyl silane) nanohybrid, with maximum sorption capacities of 49.0 (at $\mathrm{pH}=5.5$ ), 13.1 (at $\mathrm{pH}=5.0$ ) and $36.1 \mathrm{mg} / \mathrm{g}$ (at $\mathrm{pH}=4.5$ ) for $\mathrm{Cd}(\mathrm{II})$, $\mathrm{Ni}(\mathrm{II})$ and U(VI) ions, respectively. Andjelkovic et al. [15] reported Fe doped $\mathrm{TiO}_{2}$ adsorbent for As contaminated natural water treatment, and they demonstrated that this material could be used for the removal of As to the level of drinking water recommended by World Health Organization 
(WHO) without pretreatment.

While high adsorption ability was demonstrated by these studies, these adsorbents were nanosized. These materials are difficult and costly to remove from water after the adsorption process, which may cause a secondary pollution from $\mathrm{TiO}_{2}$ NPs themselves, or even result in increased toxicity $[22,23]$. In addition, these reports focused on single element removal, which is not practical in real applications. Herein, we report a novel process to prepare nanoporous, micro-sized $\mathrm{TiO}_{2} / \mathrm{SiO}_{2}$ particle adsorbent. Briefly, an ultrathin $\mathrm{TiO}_{2}$ film was conformally coated on the surface of micro-sized silica gel particles by atomic layer deposition (ALD). As a proof of concept, micro-sized silica gel particles $(35-70 \mu \mathrm{m})$ with an average pore size of $15 \mathrm{~nm}$ was chosen as the support. The nanoporous structure of silica gel can provide large surface area of $\mathrm{TiO}_{2}$ for metal ion adsorption, and the large particle size of silica gel can allow them being easily separated from water. ALD is very suitable for this application, since it is a surface controlled layer-by-layer coating process based on self-limiting surface reactions, and it has been utilized to deposit metal oxide films with nanometer-sized control of film thickness and well controlled film compositions [24-26]. It is an enabling technology for highly conformal coating over complex 3D topography structures with excellent control over stoichiometry and properties.

\section{Experimental section}

\subsection{Preparation of $\mathrm{TiO}_{2} / \mathrm{SiO}_{2}$}

$\mathrm{TiO}_{2}$ films were deposited on porous silica gel particles by ALD using titanium tetrachloride $\left(\mathrm{TiCl}_{4}\right)\left(99 \%\right.$, Alfa Aesar) and concentrated $\mathrm{H}_{2} \mathrm{O}_{2}\left(50\right.$ wt.\% in $\left.\mathrm{H}_{2} \mathrm{O}\right)$ as precursors in a fluidized 
bed reactor, as described in detail elsewhere [27]. All of the chemicals were used as received without any treatment. The silica gel particles were $35-70 \mu \mathrm{m}$ in diameter, their average pore size was $15 \mathrm{~nm}$, their pore volume was $1.04 \mathrm{~cm}^{3} / \mathrm{g}$, and their Brunauer-Emmett-Teller (BET) surface area was $268.7 \mathrm{~m}^{2} / \mathrm{g}$. For a typical run, $5 \mathrm{~g}$ of silica gel particles were loaded into the reactor. The reaction temperature was $100{ }^{\circ} \mathrm{C}$. The minimum fluidization superficial gas velocity was determined by measuring the pressure drop across the particle bed versus the superficial gas velocity of purge gas. During the ALD reaction, $\mathrm{TiCl}_{4}$ and $\mathrm{H}_{2} \mathrm{O}_{2}$ were fed separately through the distributor plate of the reactor using the driving force of their room-temperature vapor pressures. Two needle valves were used to adjust the $\mathrm{TiCl}_{4}$ and $\mathrm{H}_{2} \mathrm{O}_{2}$ flow rates and to ensure that the pressures were high enough to promote particle fluidization. The reactor was also subjected to vibration via vibrators to improve the quality of particle fluidization during the ALD coating process [28]. $\mathrm{N}_{2}$ was used as flush gas to remove unreacted precursors and any byproducts during the ALD coating process. A typical coating cycle used the following steps: $\mathrm{TiCl}_{4}$ dose, $\mathrm{N}_{2}$ purge, evacuation; concentrated $\mathrm{H}_{2} \mathrm{O}_{2}$ dose, $\mathrm{N}_{2}$ purge, evacuation. 20 and 40 cycles of $\mathrm{TiO}_{2}$ ALD films were deposited on silica gel particles. After the ALD coating, half amount of each sample was heated in air at $500{ }^{\circ} \mathrm{C}$ for $4 \mathrm{hr}$.

\subsection{Characterization}

Inductively coupled plasma - atomic emission spectroscopy (ICP-AES) was used to measure Ti mass fraction in $\mathrm{TiO}_{2} / \mathrm{SiO}_{2}$ particles with different thicknesses of $\mathrm{TiO}_{2}$ films. $\mathrm{TiO}_{2}$ mass fraction was calculated based on the ICP results. The crystal structure of $\mathrm{TiO}_{2}$ was detected by 
$\mathrm{X}$-ray diffraction (XRD) with filtered $\mathrm{Cu} \mathrm{K} \alpha$ radiation $(\lambda=1.5406 \AA$ ). The scanning range was $2 \theta$ from $20^{\circ}$ to $80^{\circ}$, with a scanning rate of $0.025 \%$ s. Scanning electron microscopy/energy-dispersive X-ray spectroscopy (SEM/EDX) was applied to observe the morphology and to analyze the surface composition of 40 cycles of $\mathrm{TiO}_{2}$ coated silica gel samples before heat treatment. A Quantachrome Autosorb-1 was used to obtain nitrogen adsorption and desorption isotherms of the uncoated and the $\mathrm{TiO}_{2}$ ALD coated particles at -196 ${ }^{\circ} \mathrm{C}$. The surface area of the particles was calculated using the BET method in a relative pressure range of $0.05-0.25$. The total pore volumes were calculated from the adsorption quantity at a relative pressure of $\mathrm{P} / \mathrm{P}_{0}=0.99$. The pore size distribution curves were derived from the adsorption branches of the isotherms using the Barrett-Joyner-Halenda (BJH) method.

\subsection{Metal and metalloid ions removal studies}

In a typical competitive adsorption experiment, a solution containing $\mathrm{As}(\mathrm{V}), \mathrm{Se}(\mathrm{IV}), \mathrm{Be}(\mathrm{II})$, $\mathrm{Al}(\mathrm{III}), \mathrm{V}(\mathrm{V}), \mathrm{Cr}(\mathrm{III}), \mathrm{Mn}(\mathrm{II}), \mathrm{Co}(\mathrm{II}), \mathrm{Ni}(\mathrm{II}), \mathrm{Cu}(\mathrm{II}), \mathrm{Zn}(\mathrm{II}), \mathrm{Ba}(\mathrm{II}), \mathrm{Tl}(\mathrm{I}), \mathrm{Sb}(\mathrm{III}), \mathrm{Cd}(\mathrm{II}), \mathrm{Ag}(\mathrm{I})$, $\mathrm{Sr}(\mathrm{II}), \mathrm{Mo}(\mathrm{VI})$, and $\mathrm{Pb}(\mathrm{II})$ in ultra-pure water was adjusted to $\mathrm{pH} 3$ or 5 in a $125 \mathrm{~mL}$ polypropylene bottle pre-cleaned with diluted $\mathrm{HNO}_{3}$. The concentration of every element ion was $500 \mu \mathrm{g} / \mathrm{L}$ in the solution. $\mathrm{pH}$ was adjusted by $0.1 \mathrm{M} \mathrm{HNO}_{3}$ or $0.1 \mathrm{M} \mathrm{NaOH}$ solutions as measured by a calibrated $\mathrm{pH}$ meter. Samples were prepared in $19 \mathrm{~mL}$ polypropylene vials pre-cleaned with $\mathrm{HNO}_{3}$ by adding adsorbent $(500 \mathrm{mg} / \mathrm{L}$ final concentration) to the $\mathrm{pH}$ adjusted solution with above-mentioned 19 elements. Samples were rotated at a low speed for $2 \mathrm{hr}$ before centrifugation at $1000 \mathrm{~g}$ for $10 \mathrm{~min}$. The supernatant was transferred to another pre-cleaned 19 
$\mathrm{mL}$ polypropylene vial and diluted with $1 \% \mathrm{HNO}_{3}$ for inductively coupled plasma - mass spectrometry (ICP-MS) analysis. The uptake amount $\mathrm{Q}_{\mathrm{e}}(\mathrm{mg} / \mathrm{g})$ and removal efficiency of elements at equilibrium can be calculated by Eqs. (1) and (2):

$$
\begin{gathered}
Q_{e}=\frac{\left(C_{i}-C_{e}\right) V}{m} \\
\text { \%removal }=\frac{100\left(C_{i}-C_{e}\right)}{C_{i}}
\end{gathered}
$$

where $C_{i}$ is the initial metal or metalloid ion concentration $(\mathrm{mg} / \mathrm{mL}), C_{e}$ is the equilibrium concentration of metal or metalloid ion $(\mathrm{mg} / \mathrm{mL}), \mathrm{V}$ is the volume of the solution $(\mathrm{mL})$ and $\mathrm{m}$ is the mass of adsorbent (g). Single adsorption experiments of $\mathrm{Sb}(\mathrm{III}), \mathrm{Cr}(\mathrm{III})$, and $\mathrm{Pb}(\mathrm{II})$ ions were also carried out following the identical procedures. The initial concentrations of metal ions and adsorbents were $500 \mu \mathrm{g} / \mathrm{L}$ and $500 \mathrm{mg} / \mathrm{L}$, respectively. This was the same as that in competitive adsorption experiments.

The competitive adsorption experiments were also carried out at $\mathrm{pH} 7$ to evaluate adsorption property of the prepared adsorbents. The original concentration of each element was around 500 $\mu \mathrm{g} / \mathrm{L}$ before the $\mathrm{pH}$ was adjusted to 7 . However, there were severe precipitation of $\mathrm{Al}, \mathrm{V}, \mathrm{Cr}, \mathrm{Cu}$, $\mathrm{As}$, and $\mathrm{Pb}$ ions in the standard solution without adsorbent when the $\mathrm{pH}$ was adjusted to 7 , as shown in the Table S1. The serious precipitation affected the adsorption results, so the adsorption experiments were carried out at $\mathrm{pH} 3$ and 5 in this study.

To verify the hypothesis that $\mathrm{TiO}_{2}$ coated porous silica gel particles can be easily separated

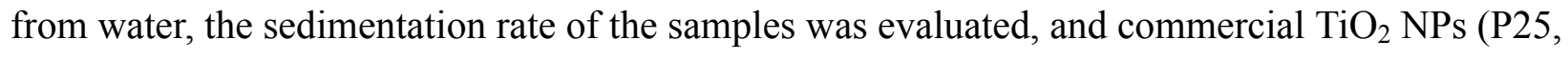
$21 \pm 5 \mathrm{~nm}$, Degussa) were used as a reference. Briefly, $50 \mathrm{mg}$ of 40 cycles of $\mathrm{TiO}_{2}$ coated $\mathrm{SiO}_{2}$ samples without heat treatment and P25 NPs were added into $1 \mathrm{~mL}$ of methylene blue (MB, 10 
$\mathrm{mg} / \mathrm{L})$ separately. The sedimentation rate of the particles was evaluated.

\section{Results and discussion}

\subsection{Adsorbent characterization}

Figure 1 shows that the $\mathrm{TiO}_{2}$ content of the particles without heat treatment increased fast with the increase in the number of ALD coating cycles, from 0 to 22 wt. $\%$ with the $\mathrm{TiO}_{2}$ ALD coating cycles less than 20 cycles, then increased slowly to $32 \%$ with the number of ALD cycles further increased. The high loading rate of $\mathrm{TiO}_{2}$ before 20 cycles of ALD coating was due to the nanoporous structure of silica gel particles. A lot of sub-nanoscale pores could be filled with $\mathrm{TiO}_{2}$, which would result in the reduction of particle surface area and pore volume, as shown in Figure 2b. $\mathrm{TiO}_{2}$ films were deposited throughout both the internal and external surfaces of silica gel particles. After 20 cycles of ALD, most of the sub-nanoscale pores were completely filled with $\mathrm{TiO}_{2}$, which resulted in a reduced growth rate of $\mathrm{TiO}_{2}$ content. Since the growth rate of $\mathrm{TiO}_{2}$ is very slow at this reaction condition [27], larger pores would not be filled with further increase of the ALD coating cycles, less than 40 cycles in this study. 


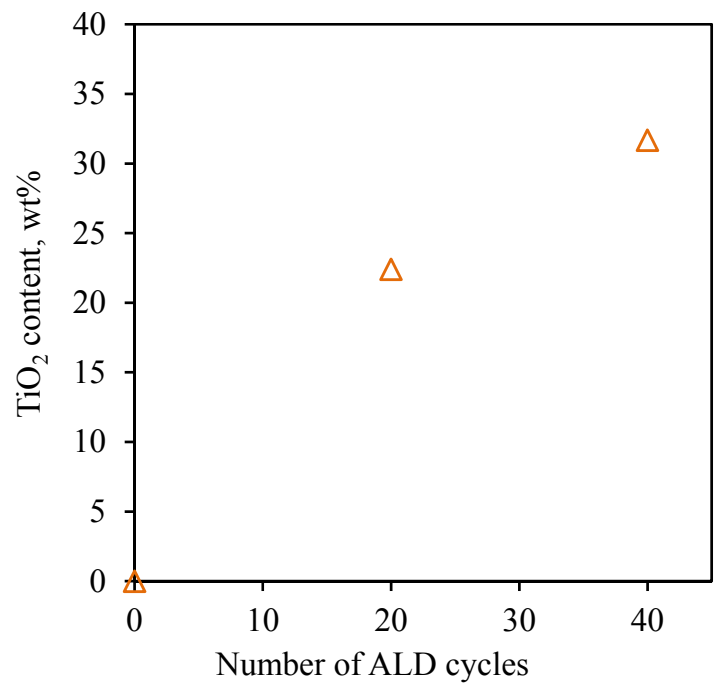

Figure 1. $\mathrm{TiO}_{2}$ content of $\mathrm{TiO}_{2}$ coated porous silica gel particles versus the number of ALD coating cycles. 

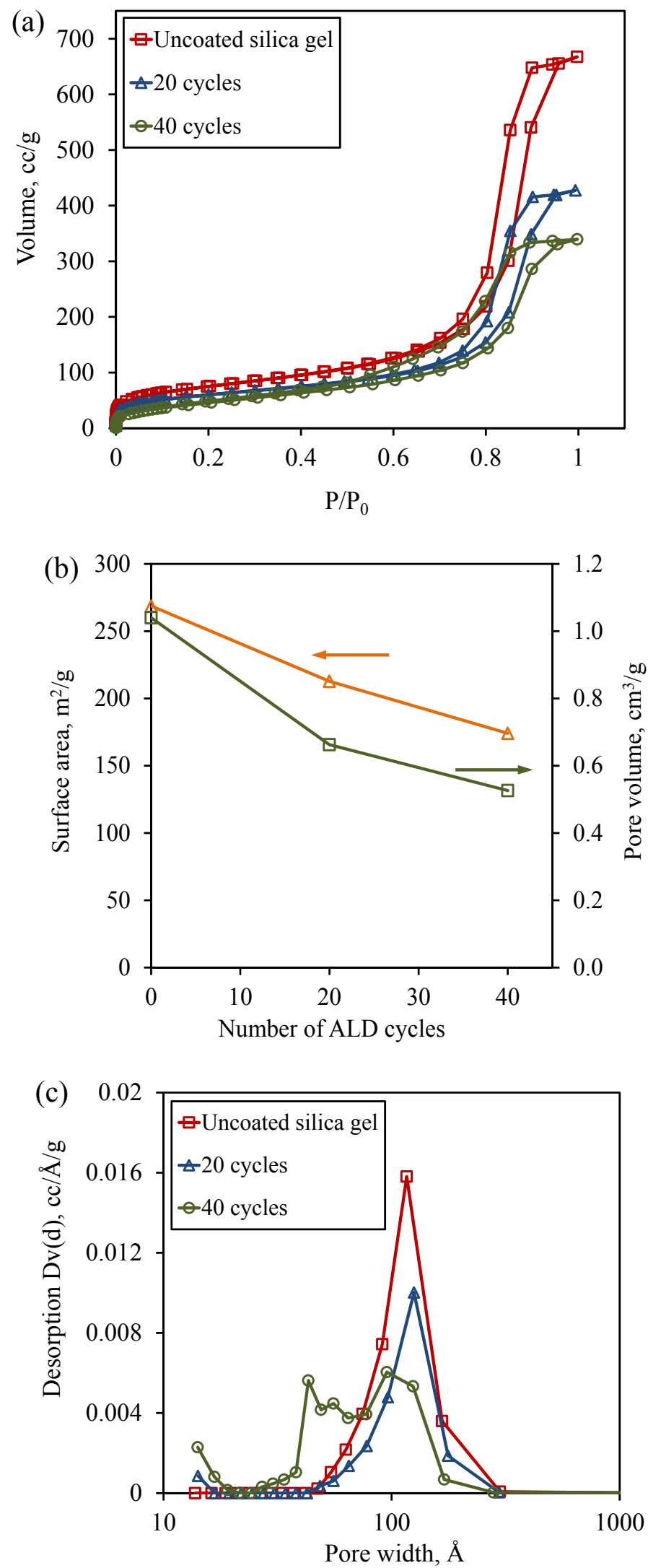
Figure 2. (a) Nitrogen adsorption and desorption isotherms, (b) surface area and pore volume, and (c) pore size distributions of uncoated and as-deposited silica gel particles coated with different thicknesses of $\mathrm{TiO}_{2}$ ALD films.

The nitrogen adsorption and desorption isotherms, surface area, pore volume, and pore size distributions of silica gel particles coated with different thicknesses of $\mathrm{TiO}_{2} \mathrm{ALD}$ films are shown in Figure 2. Hysteresis loop was seen at high relative pressure in all isotherms, suggesting that these materials had porous structures. The trend of surface area of these particles versus the number of ALD coating cycles is consistent with that of $\mathrm{TiO}_{2}$ content versus the number of ALD coating cycles. As shown in Figure $2 b$, the pore volume of samples decreased rapidly with the increase in the number of ALD coating cycles, from 1.04 to $0.66 \mathrm{~cm}^{3} / \mathrm{g}$ after 20 cycles of $\mathrm{TiO}_{2}$ coating, then it decreased to $0.53 \mathrm{~cm}^{3} / \mathrm{g}$ after additional 20 cycles of $\mathrm{TiO}_{2}$ coating. As mentioned above, since initially most of the sub-nanoscale pores were filled with $\mathrm{TiO}_{2}$, the pore volume of the particles decreased quickly during the first 20 cycles of ALD coating. As shown in Figure 2c, the pore size distribution did not shift before 20 cycles of $\mathrm{TiO}_{2}$ ALD coating, but the pore volume decreased a lot, indicating that many nanoscale pores were filled with $\mathrm{TiO}_{2}$ after the ALD coating. Then the pore size distribution shifted to the left with the increase in the number of ALD coating cycles after 20 cycles of $\mathrm{TiO}_{2}$ ALD coating, indicating a decrease of pore size. This is mainly due to the reduction of pore size and segmentation of nanoscale pores to sub-nanoscale pores by ultrathin $\mathrm{TiO}_{2}$ films inside the porous structure of the particles.

The XRD patterns of 40 cycles of $\mathrm{TiO}_{2}$ coated particles before and after heat treatment are presented in Figure 3. All broad reflections of the sample without heat treatment reflected the 
crystal structure of silica gel, so apparently the $\mathrm{TiO}_{2}$ ALD films on the samples should be amorphism totally. In contrast, the sharp reflections located at the positions $2 \theta=25.3^{\circ}, 37.8^{\circ}$, $48.1^{\circ}, 53.9^{\circ}, 55.2^{\circ}, 62.8^{\circ}$, and $75.2^{\circ}$ correspond to the reflections from (101), (004), (200), (105), (211), (204), and (215) planes of $\mathrm{TiO}_{2}$ in the anatase phase, respectively, which has a tetragonal structure for the sample after heat treatment. Peak assignments were made according to JCPDS (Cards No. 21-1276 and No. 21-1272). No rutile phase was detected. It indicates that the structure of $\mathrm{TiO}_{2}$ transferred from amorphous to tetragonal after heat treatment. The $\mathrm{TiO}_{2}$ crystal size was $11.0 \mathrm{~nm}$ after heat treatment according to the $\mathrm{XRD}$ analysis. However, the $\mathrm{TiO}_{2}$ film thickness should be less than $4 \mathrm{~nm}$ after 40 cycles of $\mathrm{TiO}_{2} \mathrm{ALD}$. Thus, it indicates that the thin $\mathrm{TiO}_{2}$ film aggregated and became large $\mathrm{TiO}_{2}$ particles with the formation of a tetragonal structure during the heat treatment, and thereby the surface area of $\mathrm{TiO}_{2}$ decreased. Carbon (C), oxygen (O), silica ( $\mathrm{Si}$ ) and titanium (Ti) were detected on the surface of 40 cycles $\mathrm{TiO}_{2}$ coated silica gel particles without heat treatment (Figure S1). EDX analysis showed that $\mathrm{TiO}_{2}$ content on the particle surface was 34.6 wt.\%, which is very close to the value measured by ICP-AES (31.7 wt.\%). This implies that $\mathrm{TiO}_{2}$ films was coated uniformly on the external surface and internal surface of the silica gel particles. 


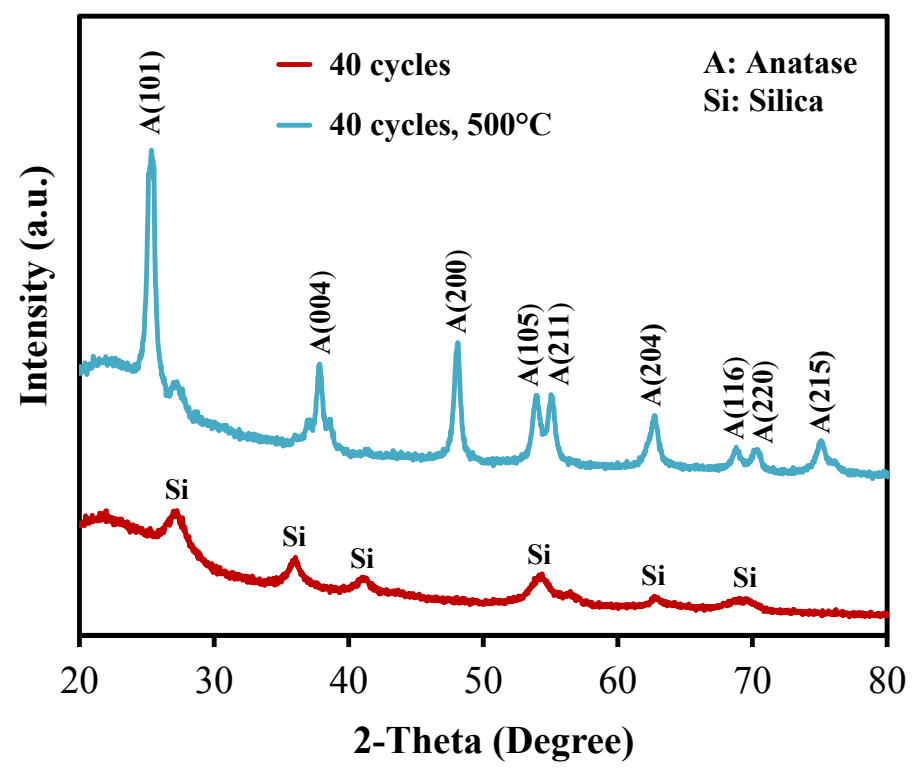

Figure 3. XRD pattern of 40 cycles of $\mathrm{TiO}_{2}$ coated silica gel particles before and after heat treatment.

\subsection{Adsorption performance}

It has been an important objective to prepare a proper adsorbent with high adsorption capability and large particle size for easy separation from water after the removal of heavy metal and metalloid ions. Due to their high porosity and micrometer scale, $\mathrm{TiO}_{2}$ coated silica gel particles with and without heat treatment were used in this study to adsorb the toxic ions. The simultaneous removal efficiency of the mixture ions of As(V), Se(IV), Be(II), Al(III), V(V), $\mathrm{Cr}(\mathrm{III}), \mathrm{Mn}(\mathrm{II}), \mathrm{Co}(\mathrm{II}), \mathrm{Ni}(\mathrm{II}), \mathrm{Cu}(\mathrm{II}), \mathrm{Zn}(\mathrm{II}), \mathrm{Ba}(\mathrm{II}), \mathrm{Tl}(\mathrm{I}), \mathrm{Sb}(\mathrm{III}), \mathrm{Cd}(\mathrm{II}), \mathrm{Ag}(\mathrm{I}), \mathrm{Sr}(\mathrm{II}), \mathrm{Pb}(\mathrm{II})$, and $\mathrm{Mo}(\mathrm{VI})$ by the uncoated and $\mathrm{TiO}_{2}$ coated silica gel particles was evaluated at different $\mathrm{pH}$ values, as shown in Tables 1 and 2. Obviously, the uncoated silica gel particles were ineffective for all ions removal at $\mathrm{pH} 3$. In contrast, the 20 cycles $\mathrm{TiO}_{2}$ coated adsorbent without heat 
treatment removed 99\% $\mathrm{As}(\mathrm{V}), 98 \% \mathrm{Se}(\mathrm{IV}), 75 \% \mathrm{~V}(\mathrm{~V}), 93 \% \mathrm{Mo}(\mathrm{VI}), 94 \% \mathrm{~Pb}(\mathrm{II}), 40 \% \mathrm{Sb}(\mathrm{III})$, and $42 \% \mathrm{Ag}(\mathrm{I})$ from the solution at $\mathrm{pH} 3$. The 40 cycles of $\mathrm{TiO}_{2}$ coated particles without heat treatment showed similar adsorption performance. After heat treatment, the 20 and 40 cycles $\mathrm{TiO}_{2}$ coated particles showed high removal efficiencies for $\mathrm{As}(\mathrm{V}), \mathrm{Se}(\mathrm{IV}), \mathrm{V}(\mathrm{V}), \mathrm{Mo}(\mathrm{VI})$ and $\mathrm{Pb}(\mathrm{II})$, but did not adsorb any $\mathrm{Sb}(\mathrm{III})$ and $\mathrm{Ag}(\mathrm{I})$ ions at $\mathrm{pH}$ 3. At $\mathrm{pH}$ 5, the simultaneous removal efficiencies of As (V), $\mathrm{Se}(\mathrm{IV}), \mathrm{V}(\mathrm{V}), \mathrm{Mo}(\mathrm{VI}), \mathrm{Pb}(\mathrm{II}), \mathrm{Sb}(\mathrm{III}), \mathrm{Ag}(\mathrm{I}), \mathrm{Cu}(\mathrm{II})$, and $\mathrm{Ba}(\mathrm{II})$ were higher than $40 \%$ for the 20 and 40 cycles of $\mathrm{TiO}_{2}$ coated particles without heat treatment. After heat treatment, the removal efficiencies decreased for some elements and increased for some other elements, and no significant change for some elements. For example, there is almost no adsorption of $\mathrm{Sb}(\mathrm{III})$ for the 20 and 40 cycles $\mathrm{TiO}_{2}$ coated silica gel particles. Instead, they removed about $45 \% \mathrm{Cr}(\mathrm{III})$ and $40 \% \mathrm{Tl}(\mathrm{I})$ simultaneously from the solution. The uncoated silica gel particles also removed 75\% V(V), 99\% $\mathrm{Pb}(\mathrm{II}), 83 \% \mathrm{Ag}(\mathrm{I})$, and 57\% $\mathrm{Cr}(\mathrm{III})$ simultaneously under this $\mathrm{pH}$ condition. The point of zero charge (PZC) of amorphous $\mathrm{TiO}_{2}$, anatase $\mathrm{TiO}_{2}$, and $\mathrm{SiO}_{2}$ was around $6.5,7.2$, and 3.5 , respectively $[29,30]$. When the $\mathrm{pH}$ value is below the PZC, $\mathrm{TiO}_{2}$ and silica gel surface is positively charged. Otherwise, it will be negatively charged. Generally, the physisorption is driven by electrostatic force between oppositely charged adsorbates and adsorbents, but for chemisorption, like charged ions can interact by chemical bond [31]. 
Table 1. Removal efficiency of metal and metalloid ions by uncoated, 20 cycles, and 40 cycles of $\mathrm{TiO}_{2}$ coated silica gel particles with/without heat treatment at $\mathrm{pH} 3$.

\begin{tabular}{|c|c|c|c|c|c|}
\hline & Uncoated & 20 cycles $\mathrm{TiO}_{2}$ & 40 cycles $\mathrm{TiO}_{2}$ & $\begin{array}{c}20 \text { cycles } \\
\mathrm{TiO}_{2}, 500{ }^{\circ} \mathrm{C}\end{array}$ & $\begin{array}{c}40 \text { cycles } \\
\mathrm{TiO}_{2}, 500{ }^{\circ} \mathrm{C}\end{array}$ \\
\hline As & $0 \%$ & $99 \%$ & $99 \%$ & $82 \%$ & $92 \%$ \\
\hline $\mathrm{Se}$ & $0 \%$ & $98 \%$ & $98 \%$ & $74 \%$ & $85 \%$ \\
\hline $\mathbf{B e}$ & $0 \%$ & $0 \%$ & $0 \%$ & $0 \%$ & $1 \%$ \\
\hline Al & $0 \%$ & $0 \%$ & $0 \%$ & $0 \%$ & $0 \%$ \\
\hline $\mathbf{V}$ & $0 \%$ & $75 \%$ & $79 \%$ & $57 \%$ & $60 \%$ \\
\hline $\mathrm{Cr}$ & $0 \%$ & $4 \%$ & $1 \%$ & $18 \%$ & $20 \%$ \\
\hline Mn & $0 \%$ & $0 \%$ & $4 \%$ & $7 \%$ & $4 \%$ \\
\hline Co & $0 \%$ & $1 \%$ & $3 \%$ & $7 \%$ & $4 \%$ \\
\hline $\mathbf{N i}$ & $0 \%$ & $0 \%$ & $0 \%$ & $0 \%$ & $0 \%$ \\
\hline $\mathbf{C u}$ & $0 \%$ & $4 \%$ & $4 \%$ & $0 \%$ & $2 \%$ \\
\hline $\mathbf{Z n}$ & $0 \%$ & $0 \%$ & $0 \%$ & $0 \%$ & $0 \%$ \\
\hline $\mathbf{S r}$ & $0 \%$ & $0 \%$ & $2 \%$ & $1 \%$ & $0 \%$ \\
\hline Mo & $0 \%$ & $93 \%$ & $91 \%$ & $99 \%$ & $99 \%$ \\
\hline Ag & $0 \%$ & $42 \%$ & $40 \%$ & $0 \%$ & $11 \%$ \\
\hline Cd & $0 \%$ & $1 \%$ & $2 \%$ & $1 \%$ & $4 \%$ \\
\hline $\mathbf{S b}$ & $0 \%$ & $40 \%$ & $56 \%$ & $0 \%$ & $2 \%$ \\
\hline $\mathbf{B a}$ & $0 \%$ & $12 \%$ & $6 \%$ & $0 \%$ & $5 \%$ \\
\hline TI & $0 \%$ & $6 \%$ & $7 \%$ & $22 \%$ & $27 \%$ \\
\hline $\mathbf{P b}$ & $0 \%$ & $94 \%$ & $94 \%$ & $92 \%$ & $94 \%$ \\
\hline
\end{tabular}


Table 2. Removal efficiency of metal and metalloid ions by uncoated, 20 cycles, and 40 cycles of $\mathrm{TiO}_{2}$ coated silica gel particles with/without heat treatment at $\mathrm{pH} 5$.

\begin{tabular}{|c|c|c|c|c|c|}
\hline & Uncoated & 20 cycles $\mathrm{TiO}_{2}$ & 40 cycles $\mathrm{TiO}_{2}$ & $\begin{array}{c}20 \text { cycles } \\
\mathrm{TiO}_{2}, 500{ }^{\circ} \mathrm{C}\end{array}$ & $\begin{array}{c}40 \text { cycles } \mathrm{TiO}_{2}, \\
500{ }^{\circ} \mathrm{C}\end{array}$ \\
\hline As & $60 \%$ & $95 \%$ & $95 \%$ & $71 \%$ & $73 \%$ \\
\hline Se & $21 \%$ & $95 \%$ & $97 \%$ & $47 \%$ & $55 \%$ \\
\hline $\mathbf{B e}$ & $11 \%$ & $0 \%$ & $0 \%$ & $0 \%$ & $0 \%$ \\
\hline Al & $28 \%$ & $0 \%$ & $0 \%$ & $26 \%$ & $18 \%$ \\
\hline $\mathbf{V}$ & $75 \%$ & $86 \%$ & $81 \%$ & $93 \%$ & $89 \%$ \\
\hline $\mathrm{Cr}$ & $57 \%$ & $0 \%$ & $0 \%$ & $46 \%$ & $45 \%$ \\
\hline Mn & $12 \%$ & $0 \%$ & $0 \%$ & $2 \%$ & $2 \%$ \\
\hline Co & $11 \%$ & $4 \%$ & $1 \%$ & $7 \%$ & $7 \%$ \\
\hline $\mathrm{Ni}$ & $11 \%$ & $0 \%$ & $0 \%$ & $3 \%$ & $1 \%$ \\
\hline $\mathbf{C u}$ & $18 \%$ & $72 \%$ & $71 \%$ & $64 \%$ & $70 \%$ \\
\hline $\mathbf{Z n}$ & $12 \%$ & $9 \%$ & $7 \%$ & $11 \%$ & $6 \%$ \\
\hline $\mathbf{S r}$ & $4 \%$ & $1 \%$ & $2 \%$ & $5 \%$ & $3 \%$ \\
\hline Mo & $10 \%$ & $94 \%$ & $91 \%$ & $97 \%$ & $97 \%$ \\
\hline Ag & $83 \%$ & $73 \%$ & $66 \%$ & $30 \%$ & $21 \%$ \\
\hline Cd & $13 \%$ & $2 \%$ & $0 \%$ & $22 \%$ & $19 \%$ \\
\hline $\mathbf{S b}$ & $0 \%$ & $40 \%$ & $52 \%$ & $3 \%$ & $1 \%$ \\
\hline $\mathbf{B a}$ & $4 \%$ & $49 \%$ & $38 \%$ & $41 \%$ & $43 \%$ \\
\hline TI & $5 \%$ & $12 \%$ & $10 \%$ & $43 \%$ & $41 \%$ \\
\hline $\mathbf{P b}$ & $99 \%$ & $60 \%$ & $57 \%$ & $73 \%$ & $70 \%$ \\
\hline
\end{tabular}

As shown in Table 1, for all $\mathrm{TiO}_{2}$ coated particles at $\mathrm{pH} 3$, the removal efficiencies of $\mathrm{As}(\mathrm{V})$ and $\mathrm{Se}(\mathrm{IV})$ were high. In contrast, there is no obvious removal efficiency for the uncoated particles. When $\mathrm{pH}$ changed to 5, the removal efficiencies of $\mathrm{As}(\mathrm{V})$ and $\mathrm{Se}(\mathrm{IV})$ almost kept constant for the $\mathrm{TiO}_{2}$ coated samples without heat treatment $(\geq 95 \%)$, but the removal efficiencies decreased for the $\mathrm{TiO}_{2}$ coated samples with heat treatment (Figure S2). The uncoated particles removed $60 \% \mathrm{As}(\mathrm{V})$ and $21 \% \mathrm{Se}(\mathrm{IV})$ simultaneously at $\mathrm{pH} 5$. At $\mathrm{pH} 3$ and 5, the surface of the $\mathrm{TiO}_{2}$ coated samples was positively charged, since the $\mathrm{PZC}$ of amorphism $\mathrm{TiO}_{2}$ and anatase $\mathrm{TiO}_{2}$ was higher than $5 . \operatorname{As}(\mathrm{V})$ and $\mathrm{Se}(\mathrm{IV})$ are commonly found in water in the form of inorganic 
species. $\mathrm{H}_{2} \mathrm{AsO}_{4}{ }^{-}$and $\mathrm{HSeO}_{3}{ }^{-}$are the dominant species in the $\mathrm{pH}$ range of 3.0-7.0 [32, 33]. The strong adsorption of $\mathrm{As}(\mathrm{V})$ and $\mathrm{Se}(\mathrm{IV})$ at $\mathrm{pH} 3$ might suggest that $\mathrm{H}_{2} \mathrm{AsO}_{4}{ }^{-}$and $\mathrm{HSeO}_{3}{ }^{-}$were adsorbed on $\mathrm{TiO}_{2}$ through electrostatic interactions for the $\mathrm{TiO}_{2}$ coated samples. At $\mathrm{pH} 3$, the removal efficiencies of $\mathrm{As}(\mathrm{V})$ and $\mathrm{Se}(\mathrm{IV})$ for the samples with heat treatment were lower than that for the samples without heat treatment. This fact could be attributed to the reduced $\mathrm{TiO}_{2}$ surface area of the particles after heat treatment. At $\mathrm{pH}$, the removal efficiencies of $\mathrm{As}(\mathrm{V})$ and Se(IV) decreased for the $\mathrm{TiO}_{2}$ coated samples with heat treatment. The single adsorption studies of $\mathrm{As}(\mathrm{V})$ and $\mathrm{Se}(\mathrm{IV})$ indicated that the adsorption performance was almost the same in the $\mathrm{pH}$ range between 3 and 5 for $\mathrm{TiO}_{2}[32,33]$. In this study, the decrease of removal efficiencies could be mainly due to the fact that more other ions were adsorbed by the samples and there was not much space left for the As(V) and Se(IV) adsorption.

For the uncoated silica gel particles, though its surface was positive charged and could attract $\mathrm{H}_{2} \mathrm{AsO}_{4}{ }^{-}$and $\mathrm{HSeO}_{3}{ }^{-}$, the $\mathrm{PZC}$ of the uncoated silica gel might be too low and thereby the interaction between metalloid ions and the particles was not strong enough to attract As(V) and $\mathrm{Se}(\mathrm{IV})$ at $\mathrm{pH} 3$. At $\mathrm{pH} 5$, the uncoated particles was negatively charged and adsorbed certain amount of metal ions. The As(V) and Se(IV) adsorption could result from electrostatic effect. Thus, the adsorption of $\mathrm{As}(\mathrm{V})$ increased from $0 \%$ at $\mathrm{pH} 3$ to $60 \%$ at $\mathrm{pH} 5$ (Figure $\mathrm{S} 2$ ).

Normally $\mathrm{As}(\mathrm{V})$ and $\mathrm{Se}(\mathrm{IV})$ occur as different species (e.g., $\mathrm{H}_{2} \mathrm{AsO}_{4}{ }^{-}, \mathrm{HAsO}_{4}{ }^{2-}$ and $\mathrm{HSeO}_{3}{ }^{-}$, $\mathrm{SeO}_{3}{ }^{2-}$ ) in water, which are affected by many factors (e.g., $\left.\mathrm{pH}\right)$. The unstable nature of As(V) and Se(IV) compounds makes it difficult to treat, resulting in treated wastes with changing toxicity and mobility according to environmental conditions [34]. In this study, the $\mathrm{TiO}_{2}$ coated samples, 
especially the ones before heat treatment, could adsorb all kinds of As(V) and Se(IV) species and showed high removal efficiencies at different $\mathrm{pH}$ values ( $\mathrm{pH} 3$ and 5). Thus, it is a potential and promising adsorbent for the removal of $\mathrm{As}(\mathrm{V})$ and $\mathrm{Se}(\mathrm{IV})$.

At $\mathrm{pH} 3$ and 5, the surface of the $\mathrm{TiO}_{2}$ coated samples was positively charged, thereby these samples mainly adsorbed metal ions through chemisorption since both the surface of the samples and metal ions (except Mo(VI)) were positively charged and cannot attract each other by physisorption. Xie et al. [29] reported that $\mathrm{Pb}(\mathrm{II})$ ions could be adsorbed through the bond between $\mathrm{Pb}^{2+}$ and Ti-O- (chemisorption). The species of $\mathrm{V}(\mathrm{V}), \mathrm{Sb}(\mathrm{III})$ and $\mathrm{Ag}(\mathrm{I})$ were $\mathrm{VO}_{2}{ }^{+}, \mathrm{Sb}^{3+}$ and $\mathrm{Ag}^{+}$, respectively, and they could be adsorbed by $\mathrm{TiO}_{2}$ coated silica gel particles through the similar process. The dominate species of $\mathrm{Mo}(\mathrm{VI})$ are $\mathrm{HMoO}_{4}{ }^{-}$and $\mathrm{MoO}_{4}{ }^{2-}$ at $\mathrm{pH} 3$ and 5 , respectively. Thus, the adsorption of molybdates could be through another process, as shown in the following reactions [35],

$$
\begin{aligned}
& \mathrm{TiOH}+\mathrm{HMoO}_{4}{ }^{-}+\mathrm{H}^{+} \rightarrow \mathrm{TiHMoO}_{4}+\mathrm{H}_{2} \mathrm{O} \\
& \mathrm{TiOH}+\mathrm{MoO}_{4}{ }^{2-}+\mathrm{H}^{+} \rightarrow \mathrm{TiMoO}_{4}{ }^{-}+\mathrm{H}_{2} \mathrm{O}
\end{aligned}
$$

The single inner-sphere surface complexes [35], $\mathrm{TiHMoO}_{4}$ and $\mathrm{TiMoO}_{4}{ }^{-}$, were the dominant adsorbed molybdates species for the $\mathrm{TiO}_{2}$ coated samples. For the uncoated silica gel particles, at pH 3 both metal ions (except Mo(VI)) and the surface of the silica gel particles were positively charged and cannot be attracted. After the $\mathrm{pH}$ was adjusted to 5, the silica gel surface changed to be negatively charged. So the sorption of $\mathrm{V}(\mathrm{V}), \mathrm{Pb}(\mathrm{II}), \mathrm{Ag}(\mathrm{I})$, and $\mathrm{Cr}(\mathrm{III})$ increased due to electrostatic attraction between the metal ions and silica gel (Figure S3). For Mo(VI) ions, though molybdates species was negatively charged and could be attracted, the $\mathrm{PZC}$ of the $\mathrm{SiO}_{2}$ 
(3.5) was so low that the surface charge of the particles might not offer enough electrostatic force between molybdates species and particles at $\mathrm{pH} 3$. It resulted in the low adsorption of Mo(VI) for the uncoated silica gel (Figure S3). Beside the electrostatic attraction, the hydrolysis of metal ions was also an important factor in the adsorption process. With the increase in $\mathrm{pH}$, the hydrolysis of metal cations increased. Hydroxyl-metal complexes (e.g., $\left.\mathrm{Cu}(\mathrm{OH})^{+}\right)$are known to adsorb with a higher affinity than the unhydrolyzed metal cations (e.g., $\left.\mathrm{Cu}^{2+}\right)$, and thereby the hydroxyl-metal complexes are easier to be adsorbed onto adsorbents [36-38]. In this study, the hydrolysis products of some metal ions formed, when $\mathrm{pH}$ increased to 5 , and consequently the efficiency of some metal removal increased (e.g., $\mathrm{Cu}(\mathrm{II}))$.

Before heat treatment, both 20 and 40 cycles of $\mathrm{TiO}_{2}$ coated silica gel particles had amorphous $\mathrm{TiO}_{2}$ structure, and the surface area and pores size of the $\mathrm{TiO}_{2}$ coated samples reduced after additional 20 cycles of $\mathrm{TiO}_{2}$ ALD coating. In comparison with the adsorption results for the 20 cycles of $\mathrm{TiO}_{2}$ coated particles at $\mathrm{pH} 5$, the simultaneous removal efficiencies of $\mathrm{V}(\mathrm{V}), \mathrm{Mo}(\mathrm{VI}), \mathrm{Pb}(\mathrm{II}), \mathrm{Ag}(\mathrm{I}), \mathrm{Cu}(\mathrm{II})$, and $\mathrm{Ba}(\mathrm{II})$ for the 40 cycles of $\mathrm{TiO}_{2}$ coated silica gel particles decreased slightly. This could be attributed to the surface area decrease of silica gel particles, which led to the reduction of adsorption sites. At $\mathrm{pH} 3$, more adsorption sites might be occupied by $\mathrm{H}_{3} \mathrm{O}^{+}$for both of these two samples, so they did not show obvious difference of removal efficiency. After heat treatment, the crystal structure of $\mathrm{TiO}_{2}$ changed to anatase and the crystal size of $\mathrm{TiO}_{2}$ particles on the silica gel particles was much larger than that before heat treatment. The 20 and 40 cycles of $\mathrm{TiO}_{2}$ coated silica gel particles with heat treatment showed similar adsorption performance. It may indicate that the $\mathrm{TiO}_{2}$ surface area of these two samples 
were similar after heat treatment.

Compared to the $\mathrm{TiO}_{2}$ coated samples without heat treatment, the removal efficiencies of $\mathrm{Sb}(\mathrm{III})$ and $\mathrm{Ag}(\mathrm{I})$ (especially $\mathrm{Sb}(\mathrm{III})$ ) were low for the $\mathrm{TiO}_{2}$ coated silica gel particles with heat treatment at $\mathrm{pH} 3$ and 5, which could be attributed to the hypothesis that $\mathrm{Sb}(\mathrm{III})$ and $\mathrm{Ag}(\mathrm{I})$ ions were much easier to be absorbed by amorphous $\mathrm{TiO}_{2}$ than anatase $\mathrm{TiO}_{2}$. Thus, the removal efficiency of $\mathrm{Sb}(\mathrm{III})$ was less than $5 \%$ for the $\mathrm{TiO}_{2}$ coated silica gel particles with heat treatment (anatase $\mathrm{TiO}_{2}$ ). To verify this hypothesis, single adsorption experiments using $\mathrm{Sb}(\mathrm{III})$ ions only were performed. At pH 5, both the 20 and 40 cycles of $\mathrm{TiO}_{2}$ coated samples with heat treatment removed $29 \%$ of $\mathrm{Sb}(\mathrm{III})$ from the solutions (Table 3 ). This proved that anatase $\mathrm{TiO}_{2}$ could adsorb $\mathrm{Sb}$ (III), but compared with amorphous $\mathrm{TiO}_{2}$, the uptake amount of $\mathrm{Sb}$ (III) was low for anatase $\mathrm{TiO}_{2}$. It is also noted that the $\mathrm{TiO}_{2}$ coated samples after heat treatment removed much more $\mathrm{Tl}(\mathrm{I})$ and $\mathrm{Cr}$ (III) than the samples before heat treatment. This could be attributed to the relative high uptake amount of $\mathrm{Tl}(\mathrm{I})$ and $\mathrm{Cr}(\mathrm{III})$ for the $\mathrm{TiO}_{2}$ coated silica gel particles with heat treatment. As shown in Table 3, the results of Cr(III) single adsorption experiments showed that the removal efficiencies were $21 \%$ and $17 \%$ for the 20 and 40 cycles of $\mathrm{TiO}_{2}$ coated silica gel particles without heat treatment at $\mathrm{pH} 5$, respectively. It indicated that the amorphous $\mathrm{TiO}_{2}$ could adsorb $\mathrm{Cr}(\mathrm{III})$ ions, but the uptake amount was not high. The results also showed that the competitive adsorption was real occurring in the experiments and it affected the removal efficiencies of different ions partly. Similar phenomenon was observed in the study on competitive adsorption of $\mathrm{Pb}(\mathrm{II}), \mathrm{Cd}(\mathrm{II}), \mathrm{Cu}(\mathrm{II})$ and $\mathrm{Cr}(\mathrm{III})$ ions onto titanate nanotubes by Liu et al. [39]. 
Table 3. Results of single adsorption experiments of $\mathrm{Sb}$ (III), $\mathrm{Cr}$ (III), and $\mathrm{Pb}$ (II) ions by the 20 cycles and 40 cycles of $\mathrm{TiO}_{2}$ coated silica gel particles with/without heat treatment at pH 5 .

\begin{tabular}{ccccc}
\hline & $\mathbf{2 0}$ cycles & $\mathbf{4 0}$ cycles & $\mathbf{2 0}$ cycles, $\mathbf{5 0 0}{ }^{\circ} \mathbf{C}$ & $\mathbf{4 0}$ cycles, $\mathbf{5 0 0}{ }^{\circ} \mathbf{C}$ \\
\hline $\mathrm{Sb}(\mathrm{III})$ & - & - & $29 \%$ & $29 \%$ \\
$\mathrm{Cr}(\mathrm{III})$ & $21 \%$ & $17 \%$ & - & - \\
$\mathrm{Pb}(\mathrm{II})$ & $71 \%$ & $76 \%$ & $100 \%$ & $100 \%$ \\
\hline
\end{tabular}

For all samples, the removal efficiency of $\mathrm{Pb}(\mathrm{II})$ reduced as $\mathrm{pH}$ increased from 3 to 5 (Figure $\mathrm{S} 4$ ), which is probably due to the fact that other metal ions occupied more adsorption sites at $\mathrm{pH}$ 5 and less sites were available for $\mathrm{Pb}$ (II). $\mathrm{Pb}$ (II) single adsorption experiments were carried out to verify this assumption. The results showed that more than $70 \%$ and $90 \%$ of $\mathrm{Pb}(\mathrm{II})$ was removed from the solution for the $\mathrm{TiO}_{2}$ coated samples without and with heat treatment at $\mathrm{pH}$, respectively (Table 3). The removal efficiency was higher than that in competitive adsorption case. Thus, in the experiment with mixed ions, the decrease of $\mathrm{Pb}(\mathrm{II})$ removal efficiency at $\mathrm{pH} 5$ should be due to the competitive adsorption between $\mathrm{Pb}(\mathrm{II})$ and other ions.

The simultaneous uptake amounts of $\mathrm{As}(\mathrm{V}), \mathrm{Se}(\mathrm{IV}), \mathrm{V}(\mathrm{V}), \mathrm{Pb}(\mathrm{II})$, and $\mathrm{Mo}(\mathrm{VI})$ were 0.99 , $0.98,0.79,0.91$ and $0.91 \mathrm{mg} / \mathrm{g}$ at $\mathrm{pH} 3$ for the the 40 cycles of $\mathrm{TiO}_{2}$ coated particles without heat treatment, respectively. At pH 5, the uptake amounts of As(V), Se(IV), V(V), Sb(III), Ag(I), and $\mathrm{Cu}(\mathrm{II})$ increased to $0.95,0.97,0.81,0.52,0.66$ and $0.71 \mathrm{mg} / \mathrm{g}$, respectively. Compared to other studies, the uptake amounts in this work were not high. This can be explained by the following two reasons. First, the surface area of our adsorbent is low due to the relative low surface area of the silica gel particles used in this study. Thus, the adsorbents only offered relative limited 
adsorption sites. Second, there were 19 different metal and metalloid ions in the solution and they could competitively occupy the limited adsorption sites of $\mathrm{TiO}_{2}$, which affected the sorption performance of each other. This phenomenon has also been mentioned by Youssef and Malhat [13]. In their study, $\mathrm{TiO}_{2}$ nanowires were used to remove $\mathrm{Pb}(\mathrm{II}), \mathrm{Cu}(\mathrm{II}), \mathrm{Zn}(\mathrm{II}), \mathrm{Cd}(\mathrm{II})$, and $\mathrm{Fe}(\mathrm{III})$ in a solution simultaneously and the adsorption capacities of $\mathrm{Pb}(\mathrm{II}), \mathrm{Cu}(\mathrm{II}), \mathrm{Zn}(\mathrm{II}), \mathrm{Cd}(\mathrm{II})$, and Fe(III) were only $0.48,0.38,0.17,0.32$, and $0.40 \mathrm{mg} / \mathrm{g}$, respectively [13]. In our current study, 19 different ions were simultaneously involved in the adsorption process, and the uptake amounts were still much higher.

Generally, it is more difficult to remove metal and metalloid ions from acidic solutions than from neutral and basic solutions, since some elements are easy to precipitate in the neutral and basic solutions, as shown in Table $\mathrm{S} 1$. In this study, the 20 and 40 cycles of $\mathrm{TiO}_{2}$ coated silica gel particles without heat treatment showed good adsorption performance for $\mathrm{V}(\mathrm{V}), \mathrm{Mo}(\mathrm{VI}), \mathrm{Pb}(\mathrm{II})$, $\mathrm{Sb}(\mathrm{III}), \mathrm{Ag}(\mathrm{I}), \mathrm{Cu}(\mathrm{II}), \mathrm{Ba}(\mathrm{II}), \mathrm{As}(\mathrm{V})$, and $\mathrm{Se}(\mathrm{IV})$ ions in acidic and even highly acidic medium. It is a highly practical adsorbent because none of wastewater contains only one element ion at neutral $\mathrm{pH}$ in industry. Moreover, the desorption and regeneration of $\mathrm{TiO}_{2} / \mathrm{SiO}_{2}$ samples are easy to carry out using $\mathrm{HNO}_{3}$ solution [40] or ethylenediaminetetraacetic acid (EDTA) [41]. This regeneration process is adopted widely and thereby it could save the cost and reduce waste production since both $\mathrm{TiO}_{2}$ and $\mathrm{SiO}_{2}$ are stable in acidic condition. Compared to the $\mathrm{TiO}_{2} / \mathrm{SiO}_{2}$ samples, the regeneration of activated carbon, a conventional adsorbent, is difficult under common conditions [41]. Thus, this is a big advantage to be a practical adsorbent for $\mathrm{TiO}_{2} / \mathrm{SiO}_{2}$ samples in the future. 
In summary, the performance of the novel $\mathrm{TiO}_{2}$ coated adsorbent on the removal of heavy metal ions is quite promising, especially for the adsorption of $\mathrm{V}(\mathrm{V}), \mathrm{Pb}(\mathrm{II})$, and $\mathrm{Mo}(\mathrm{VI})$ in acidic solution. Unsaturated oxygen bond and high chemisorption ability of $\mathrm{TiO}_{2}$ could be the key reason for the difference of sorption capability between the uncoated and the $\mathrm{TiO}_{2}$ coated particles [29]. Compared to the uncoated silica gel particles, $\mathrm{TiO}_{2}$ coating brought unsaturated oxygen bond, which can interact with metal ions by chemical bond and then improve the sorption capability greatly in acidic solution [29]. The strategy of $\mathrm{TiO}_{2}$ ALD coating is a universal and effective method to prepare different adsorbents for water treatment. $\mathrm{TiO}_{2}$ can be coated on various substrates besides silica gel particles through ALD, such as high surface area active carbon and $\mathrm{Al}_{2} \mathrm{O}_{3}$ substrates. Compared to other preparation methods, $\mathrm{TiO}_{2}$ can be coated on substrates over complex 3D topography structures uniformly, which can take full advantage of the high surface area of substrates.

\subsection{Sedimentation experiments}

Since $\mathrm{TiO}_{2}$ particles are white and difficult to be observed in water, so methyl blue (MB) solution was chosen in the following experiments. As we know, $\mathrm{TiO}_{2}$ can adsorb $\mathrm{MB}$ [42] and the particles would change to blue, then the sedimentation of particles can be observed easily. As shown in Figure 4a, after the silica gel particles coated with 40 cycles of $\mathrm{TiO}_{2}$ (without heat treatment) were added in the MB solution for $2 \mathrm{~min}$, all particles settled down and the solution changed to clear completely. In contrast, for the case of P25, the solution was still turbid after 60 min, as shown in Figure $4 \mathrm{~b}$. This proved that most P25 NPs did not settle down. Thus, the 
prepared nanoporous microparticles are much faster and easier to be separated from solutions.

(a)

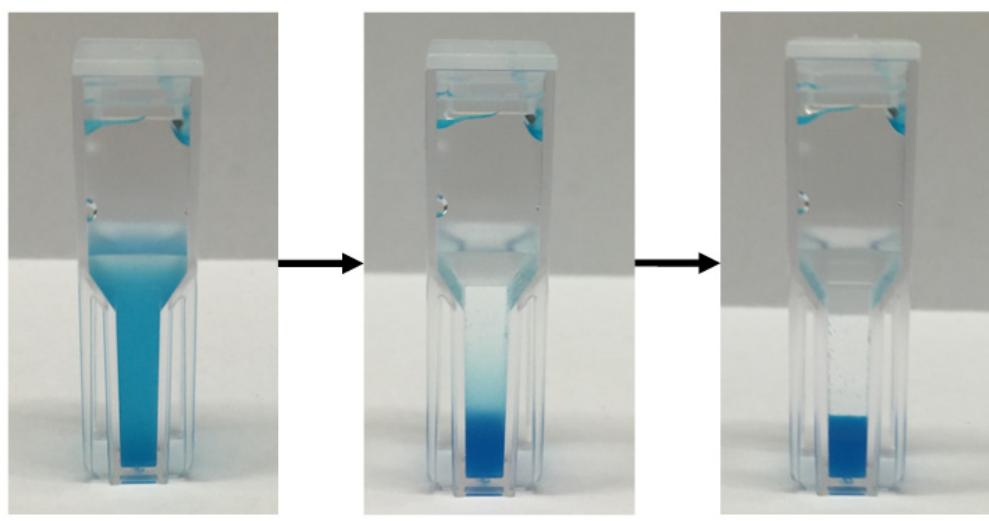

At the beginning

(b)

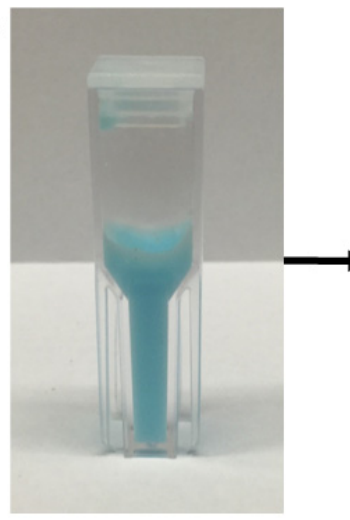

At the beginning
After 1 min

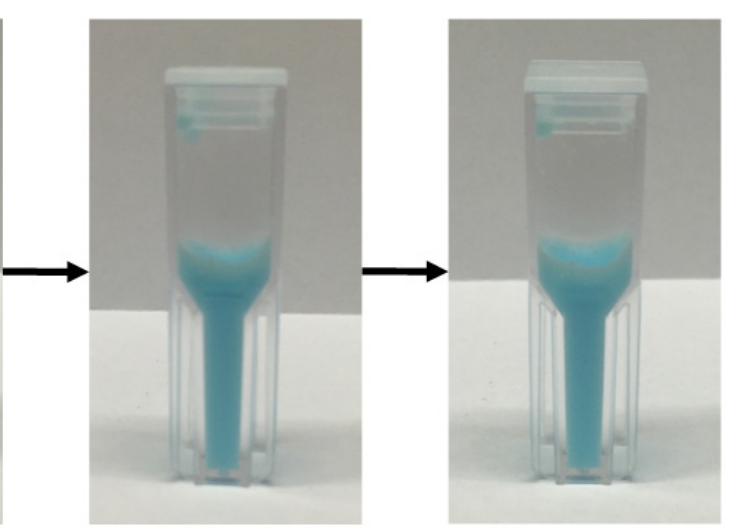

After 5 min

After 60 min

Figure 4. Sedimentation of (a) 40 cycles of $\mathrm{TiO}_{2}$ coated silica gel particles without heat treatment and (b) P25 NPs in MB solution.

\section{Conclusion}

Ultrathin $\mathrm{TiO}_{2}$ films were deposited on nanoporous, micron-sized silica gel particles by ALD in a fluidized bed reactor. At pH 3 and 5, the 20 and 40 cycles of $\mathrm{TiO}_{2}$ coated particles without heat treatment could efficiently remove $\mathrm{As}(\mathrm{V}), \mathrm{Se}(\mathrm{IV}), \mathrm{V}(\mathrm{V}), \mathrm{Mo}(\mathrm{VI}), \mathrm{Pb}(\mathrm{II}), \mathrm{Sb}(\mathrm{III}), \mathrm{Ag}(\mathrm{I})$, $\mathrm{Cu}(\mathrm{II})$, and $\mathrm{Ba}(\mathrm{II})$ ions simultaneously. The heat treatment of the $\mathrm{TiO}_{2}$ coated particles affected their adsorption performance a lot. This might be due to the decreased $\mathrm{TiO}_{2}$ surface area during 
the heat treatment. Compared to other adsorbents, the $\mathrm{TiO}_{2}$ coated particles showed good performance in acidic medium and could remove different metal and metalloid ions at the same time. In addition, this novel micro-sized adsorbent (30-75 $\mu \mathrm{m}$ particle size) is very easy to be separated and will not cause a second pollution. This is a big advantage, as compared to the $\mathrm{TiO}_{2}$ NPs adsorbent.

\section{Acknowledgments}

This work was supported in part by the National Science Foundation grant NSF CBET 1402122 and in part by Environmental Research Center at Missouri University of Science and Technology.

\section{References}

[1] Peraza, M.A., et al., Effects of micronutrients on metal toxicity. Environmental Health Perspectives, 1998. 106(SUPPL. 1): p. 203-216.

[2] Li, L., et al., Adsorption property of Cr(VI) on magnetic mesoporous titanium dioxidegraphene oxide core-shell microspheres. New Journal of Chemistry, 2014. 38(12): p. 6008-6016.

[3] Mishra, S.P., Adsorption-desorption of heavy metal ions. Current Science, 2014. 107(4): p. 601-612.

[4] Shoushtari, A.M., M. Zargaran, and M. Abdouss, Preparation and characterization of high efficiency ion-exchange crosslinked acrylic fibers. Journal of Applied Polymer 
Science, 2006. 101(4): p. 2202-2209.

[5] Gupta, V.K., R.N. Goyal, and R.A. Sharma, Comparative studies of neodymium (III)-selective PVC membrane sensors. Analytica Chimica Acta, 2009. 647(1): p. 66-71.

[6] Yin, J. and B. Deng, Polymer-matrix nanocomposite membranes for water treatment. Journal of Membrane Science, 2015. 479: p. 256-275.

[7] Mellah, A., S. Chegrouche, and M. Barkat, The precipitation of ammonium uranyl carbonate (AUC): Thermodynamic and kinetic investigations. Hydrometallurgy, 2007. 85(2-4): p. 163-171.

[8] Jakob, A., S. Stucki, and R.P.W.J. Struis, Complete heavy metal removal from fly ash by heat treatment: Influence of chlorides on evaporation rates. Environmental Science and Technology, 1996. 30(11): p. 3275-3283.

[9] Qian, H., et al., Electrostatic self-assembly of $\mathrm{TiO}_{2}$ nanoparticles onto carbon spheres with enhanced adsorption capability for Cr(VI). Materials Letters, 2012. 68: p. 174-177.

[10] Wu, S., et al., Construction of porous chitosan-xylan-TiO $\mathrm{T}_{2}$ hybrid with highly efficient sorption capability on heavy metals. Journal of Environmental Chemical Engineering, 2014. 2(3): p. 1568-1577.

[11] Mahdavi, S., M. Jalali, and A. Afkhami, Heavy metals removal from aqueous solutions using $\mathrm{TiO}_{2}, \mathrm{MgO}$, and $\mathrm{Al}_{2} \mathrm{O}_{3}$ nanoparticles. Chemical Engineering Communications, 2013. 200(3): p. 448-470.

[12] Zhang, L. and Y. Zhang, Adsorption characteristics of hexavalent chromium on $\mathrm{HCB} / \mathrm{TiO}_{2}$. Applied Surface Science, 2014. 316: p. 649-656. 
[13] Youssef, A.M. and F.M. Malhat, Selective removal of heavy metals from drinking water using titanium dioxide nanowire. Macromolecular Symposia, 2014. 337(1): p. 96-101.

[14] Abbasizadeh, S., A.R. Keshtkar, and M.A. Mousavian, Sorption of heavy metal ions from aqueous solution by a novel cast $\mathrm{PVA} / \mathrm{TiO} \mathrm{O}_{2}$ nanohybrid adsorbent functionalized with amine groups. Journal of Industrial and Engineering Chemistry, 2014. 20(4): p. 1656-1664.

[15] Andjelkovic, I., et al., Fe doped $\mathrm{TiO}_{2}$ prepared by microwave-assisted hydrothermal process for removal of $A s(I I I)$ and $A s(V)$ from water. Industrial and Engineering Chemistry Research, 2014. 53(27): p. 10841-10848.

[16] Gupta, V.K., et al., Adsorption of carmoisine A from wastewater using waste materials—Bottom ash and deoiled soya. Journal of Colloid and Interface Science, 2009. 335(1): p. 24-33.

[17] Gupta, V.K. and A. Rastogi, Biosorption of hexavalent chromium by raw and acid-treated green alga Oedogonium hatei from aqueous solutions. Journal of Hazardous Materials, 2009. 163(1): p. 396-402.

[18] Gupta, V.K. and S. Sharma, Removal of zinc from aqueous solutions using bagasse fly ash - a low cost adsorbent. Industrial and Engineering Chemistry Research, 2003. 42(25): p. $6619-6624$.

[19] Moafi, H.F., A.F. Shojaie, and M.A. Zanjanchi, Photoactive polyacrylonitrile fibers coated by nano-sized titanium dioxide: Synthesis, characterization, thermal investigation. Journal of the Chilean Chemical Society, 2011. 56(1): p. 610-615. 
[20] Engates, K.E. and H.J. Shipley, Adsorption of $\mathrm{Pb}, \mathrm{Cd}, \mathrm{Cu}, \mathrm{Zn}$, and Ni to titanium dioxide nanoparticles: Effect of particle size, solid concentration, and exhaustion. Environmental Science and Pollution Research, 2011. 18(3): p. 386-395.

[21] Dukić, A.B., et al., Simultaneous removal of $\mathrm{Pb}^{2+}, \mathrm{Cu}^{2+}, \mathrm{Zn}^{2+}$ and $\mathrm{Cd}^{2+}$ from highly acidic solutions using mechanochemically synthesized montmorillonite-kaolinite/TiO ${ }_{2}$ composite. Applied Clay Science, 2015. 103: p. 20-27.

[22] Hu, J., et al., Quantifying the effect of nanoparticles on As(V) ecotoxicity exemplified by nano- $\mathrm{Fe}_{2} \mathrm{O}_{3}$ (magnetic) and nano- $\mathrm{Al}_{2} \mathrm{O}_{3}$. Environmental Toxicology and Chemistry, 2012. 31(12): p. 2870-2876.

[23] Wang, D., et al., Synergistic toxic effect of nano-TiO ${ }_{2}$ and $\mathrm{As}(\mathrm{V})$ on ceriodaphnia dubia. Science of the Total Environment, 2011. 409(7): p. 1351-1356.

[24] Shang, Z., et al., Encapsulation of supported metal nanoparticles with an ultra-thin porous shell for size-selective reactions. Chemical Communications, 2013. 49(86): p. 10067-10069.

[25] George, S.M., Atomic layer deposition: An overview. Chemical Reviews, 2010. 110(1): p. $111-131$.

[26] Puurunen, R.L., Surface chemistry of atomic layer deposition: A case study for the trimethylaluminum/water process. Journal of Applied Physics, 2005. 97: p. 1-52.

[27] Liang, X.H., et al., Biocompatible interface films deposited within porous polymers by atomic layer deposition (ALD). ACS Applied Materials and Interfaces, 2009. 1(9): p. 1988-1995. 
[28] Patel, R.L., Y.B. Jiang, and X.H. Liang, Highly porous titania films coated on sub-micron particles with tunable thickness by molecular layer deposition in a fluidized bed reactor. Ceramics International, 2015. 41(2): p. 2240-2246.

[29] Xie, X. and L. Gao, Effect of crystal structure on adsorption behaviors of nanosized $\mathrm{TiO}_{2}$ for heavy-metal cations. Current Applied Physics, 2009. 9(3 SUPPL.): p. S185-S188.

[30] Joppien, G.R., Characterization of adsorbed polymers at the charged silica aqueous electrolyte interface. The Journal of Physical Chemistry, 1978. 82(20): p. 2210-2215.

[31] Pattanaik, M. and S.K. Bhaumik, Adsorption behaviour of polyvinyl pyrrolidone on oxide surfaces. Materials Letters, 2000. 44(6): p. 352-360.

[32] Pena, M., et al., Adsorption mechanism of arsenic on nanocrystalline titanium dioxide. Environmental Science and Technology, 2006. 40(4): p. 1257-1262.

[33] Zhang, L., et al., Sorption behavior of nano-TiO ${ }_{2}$ for the removal of selenium ions from aqueous solution. Journal of hazardous materials, 2009. 170(2): p. 1197-1203.

[34] Aredes, S., B. Klein, and M. Pawlik, The removal of arsenic from water using natural iron oxide minerals. Journal of Cleaner Production, 2012. 29: p. 208-213.

[35] Saripalli, K.P., B.P. McGrail, and D.C. Girvin, Adsorption of molybdenum on to anatase from dilute aqueous solutions. Applied geochemistry, 2002. 17(5): p. 649-656.

[36] James, R.O. and T.W. Healy, Adsorption of hydrolyzable metal ions at the oxide-water interface. III. A thermodynamic model of adsorption. Journal of Colloid and Interface Science, 1972. 40(1): p. 65-81.

[37] Wang, X., L. Hua, and Y. Ma, A biotic ligand model predicting acute copper toxicity for 
barley (Hordeum vulgare): Influence of calcium, magnesium, sodium, potassium and $\mathrm{pH}$. Chemosphere, 2012. 89(1): p. 89-95.

[38] Dai, C. and Y. Hu, Fe(III) hydroxide nucleation and growth on quartz in the presence of $\mathrm{Cu}(I I), \mathrm{Pb}(I I)$, and $\mathrm{Cr}(I I I):$ Metal hydrolysis and adsorption. Environmental science \& technology, 2014. 49(1): p. 292-300.

[39] Liu, W., et al., Adsorption of $\mathrm{Pb}^{2+}, \mathrm{Cd}^{2+}, \mathrm{Cu}^{2+}$ and $\mathrm{Cr}^{3+}$ onto titanate nanotubes: competition and effect of inorganic ions. Science of the Total Environment, 2013. 456: p. $171-180$.

[40] Liu, Y., P. Liang, and L. Guo, Nanometer titanium dioxide immobilized on silica gel as sorbent for preconcentration of metal ions prior to their determination by inductively coupled plasma atomic emission spectrometry. Talanta, 2005. 68(1): p. 25-30.

[41] Li, Q., H. Su, and T. Tan, Synthesis of ion-imprinted chitosan-TiO $\mathrm{O}_{2}$ adsorbent and its multi-functional performances. Biochemical Engineering Journal, 2008. 38(2): p. 212-218.

[42] Seo, H.O., et al., Nanoporous $\mathrm{TiO}_{2} / \mathrm{SiO}_{2}$ prepared by atomic layer deposition as adsorbents of methylene blue in aqueous solutions. Chemical Engineering Journal, 2012. 183: p. 381-386. 